\title{
Harmonisation of European
} contract law and legal translation: a role for comparative lawyers

\author{
Maria Vittoria Onufrio \\ University of Palermo
}




\begin{abstract}
The problem of harmonising the contract in Europe has caught the interest of law professors, researchers and the European institutions. After years of debates, the European Union is aware that a lack of uniform legal terminology prevents any kind of unification and harmonisation of European Contract law. The need for a uniform legal terminology clashes with the multilingual legal terminology of European law. In Europe there is not just one, but many legislative and administrative languages, and each of them is an official language of the European institutions. In accordance with the principle of linguistic equality, the European Community (EC) recognises that all legal instruments have to be drawn up and published in all the official languages of the Member States. But every linguistic version of the same European legal instrument has not a functional and teleological equivalence of meaning, since every language reflects the legal culture of a specific legal system. Instead of suggesting a solution to the conflict between linguistic equality and the need for uniform legal terminology, the article focuses on the dangers of legal translation and claims a role for the comparative lawyer in the process of harmonisation of European Contract law.
\end{abstract}

\title{
Summary
}

1. The conflict between law and language: the boundaries of the problem

2. The peculiarities of legal translation

3. The lack of common concepts and the consequent problems of translation process

4. The lack of coherency of the European legislator and its impact in the national process of implementation of European Directives

5. Towards a common legal terminology?

6. Some conclusions

7. Bibliography 


\section{The conflict between law and language: the boundaries of the problem}

The problem of unification and harmonisation of European Private law ${ }^{1}$ in the field of contract has caught the interest of law professors, researchers and the European institutions. After years of academic debates, it is accepted that unification, or even harmonisation of the European law, is not possible without the creation of uniform legal terminology, preferably in a single language or in a limited number of language versions (VAN ERP, 2002, p. 1). But the need for uniform legal terminology clashes with multilingual legal terminology of European law. In accordance with the principle of linguistic equality, the EC recognises that regulations and other legal instruments have to be drafted in all the official languages of the Member States. But every linguistic version of the same European legal instrument has not a linguistic, systematic, functional and teleological equivalence of meaning (URBAN, 2000, p. 55). Every language reflects the legal culture of a specific legal system. Especially in an enlarged Europe, where the European legal instruments have to be translated into twenty-one official languages, linguistic equality causes many complex and costly problems of translation. Legal translation is often a hazardous and dangerous process, full of hidden traps. Legal translation is not an approximate process which focuses only on linguistic side, since it implies the transposition of legal concepts from a system to another, with the consequent employment of comparative law and its methodology (IORATTI FERRARI, 2005, p. 1553).

\section{The peculiarities of legal translation}

Legal translation faces more difficulties and demands a higher degree of precision than a translation in others contexts. One of the difficulties appears in relation to the use of abstract categories. Especially in the field of Private law the translation is bound to use of abstractions, whose meaning derives from the history, the social context and the cultural changing of the legal tradition concerned (ROTMAN, 1995, p. 189). In Europe there are two legal traditions: the civil law tradition and the common law tradition. Even if these law traditions are drawing progressively closer and the boundaries between them are more porous, they reflect different law categories, concepts and taxonomies. For this reason, translating civil law terms into common law terms is a dangerous process that needs care and deep knowledge and understanding of both legal traditions.

As a consequence, legal translation requires two basic skills: on the one hand, knowledge of languages of both legal systems and, on the other hand, deep knowledge and understanding of

\footnotetext{
${ }^{1}$ It is impossible to list all the activities in the field of European Private law, but let me mention some of them: the Acquis Group (H. Schulte-NÖlKe, R. Schulze and L. Bernardeau, 2002); the Casebooks on European law (W. Van Gerven, J. Lever and P. Larouche, 2000; H. Beale, H. Kötz, A. HartKamp and D. Tallon, 2002); the Common Core Project (M. Bussani and U. MATTEI, 2000); the Pavia Group (European Contract Code - Preliminary Draft); the Study Group on European Civil Code, (C. VON BAR and O. LANDO, 2002; O. Lando, 2000 ; A. HARTKAMP, 1994); Gandolfi Group (GANDOLFI, 1992).
} 
the subject in the legal system concerned. To provide a good translation, the translator must be familiar with the legal culture of the target language in order to reformulate an equivalent meaning through what he or she judges to be the most appropriate legal term (ROTMAN, 1995, p. 189). Legal translation is not an automatic process, but it links different legal systems. To understand a legal culture of a given country the translator must focus not only on legal rules, concepts and categories, but also on customs and the social context of the legal system concerned. Law is the product of the society where it functions and it cannot be captured by a set of organised rules. Probably an interdisciplinary approach which takes into consideration the culture of the legal system could be very useful.

The comparative lawyer, who has acquaintance with the legal culture of the target language and uses an interdisciplinary approach, might provide a better translation than a perfectly bilingual translator without knowledge of the law, or even a perfectly bilingual translator who knows about only one of the two legal systems (SCHROTH, 1986, p. 53). Despite his high knowledge of both legal systems, the comparative lawyer is aware that, since a legal concept is an expression of a given legal system, he cannot find a perfect equivalent term in another language and he can only aim for an approximate equivalence, as the best result of a translation. Actually, "the concepts that are developed within one jurisdiction do not correspond to the concepts developed in other systems" (SACCO, 2005, p. 9). When someone uses his or her own legal language to interpret information from another legal system, the information is processed in the categories of his or her own system, which creates distortions (GERBER, 2005, p. 46).

Sometimes the translator finds terms for which there are not terms which have equivalent legal meanings in another language. For instance, in the Italian legal system there are no words that express the English concepts of "estoppel", "consideration" and "undue influence". In such situations, the translator may have to resort to neologism or to the repetition of the word in its original language.

On the contrary, sometimes a single legal term can cover many different concepts. Moreover, a term has a meaning in Private law different from the meaning it has in Public law. In such situations, the translator should pay a higher degree of attention.

\section{The lack of common concepts and the consequent problems of translation process}

The concept of "contract" is a good starting point to analyze the obstacles to the harmonisation of European contract world due to the lack of common concepts. The terms "contratto", "contract", "contrat", "vertrag" and "dogovori" are not interchangeable. For the French, the Italian and the German system donation is a contract, whereas for the English system it is not (SACCO, 1995, p. 138). For the French, marriage is a contrat, but it is not for the German, Italian or English (Pozzo, 2003, p. 758). The continental "contratto" does not carry with the English idea of consideration. Consideration is a peculiar requirement of the contract in common law systems, so it is difficult to translate into other legal systems (WHINCUP, 1996, p. 55). The basic idea is reciprocity and 
mutuality. Consideration must necessarily be given in return for the promise. As a result, the benefit conferred or the detriment suffered. Otherwise, a promise without the requirement of consideration cannot be enforceable. Unlike the English law, the continental concept of "contract" is based on the agreement and the concept of "causa", instead of the reciprocity of an obligation. The concept of "causa" is an expression of civil legal culture and it is not the same as the English concept of "consideration". For example, under the Italian law the expression causa can be defined as the social and economic function of a contract (BETTI, 1957, p. 32). As a consequence, it is not possible to translate the term "causa" with the term "consideration". Nonetheless, even the French term "causa" is different from the Italian "causa" (LÓPEZ RODRíGUEZ, 2004).

Another example useful for our purposes is the figure of the Italian rescissione. If a jurist is called to translate the term "rescissione" into English language, he or she cannot use the term "rescission". Despite the literacy assonance, "rescission" and "rescissione" express two different concepts. In the English system the term "rescission" is an equitable remedy used for the cancellation of a contract in case of a pre-contractual fault. In the Italian system "rescissione" is a remedy used just in the following two cases: firstly, if a party assumes an obligation under unfair conditions to save someone from suffering a serious personal injury, as long as it is known to the other party 2 ; secondly, if there is a disproportion between the performance of one party and the one of the other, and such disproportion was the result of a state of need, of which the other has availed ${ }^{3}$. Probably the English term "rescission" could be translated with the Italian term "risoluzione" , although both are not completely synonymous.

However, the problem of translation does not decrease if a jurist is called to analyse the concept of "rescissione" into the systems belonging to the same legal tradition. In fact, translating the Italian term "rescissione" with the French term "rescission" is difficult too. The French Code Civil considers rescission as a particular case of the action of nullity, used when a contract is affected by dol, violence or erreur ${ }^{5}$. Besides, according to the French Code Civil, the contract can be rescinded only regarding particular cases or towards particular parties (POZZO, 2003, p. 762). As a result, it is difficult to translate "rescission" with "rescissione". Instead in German law there is no term to translate the Italian "rescissione". The fact that there is no term does not mean that there is no

\footnotetext{
2 Art. 1447 Italian Civil Code states for the case of a "contratto concluso in istato di pericolo" that "[i]l contratto con cui una parte ha assunto obbligazioni a condizioni inique, per la necessità, nota alla controparte, di salvare sé o altri dal pericolo attuale di un danno grave alla persona, può essere rescisso sulla domanda della parte che si è obbligata (...)".

3 Art. 1448 Italian Civil Code rules the "azione generale di rescissione per lesione": "[s]e vi è sproporzione tra la prestazione di una parte e quella dell'altra, e la sproporzione è dipesa dallo stato di bisogno di una parte, del quale l'altra ha approfittato per trarne vantaggio, la parte danneggiata può domandare la rescissione del contratto (...)".

4 Art. 1454 Italian Civil Code states for the case of dissolution of contract for non-performance that "[a]lla parte inadempiente l'altra può intimare per iscritto di adempiere in un congruo termine, con dichiarazione che, decorso inutilmente detto termine, il contratto s'intenderà senz'altro risoluto.Il termine non può essere inferiore a quindici giorni, salvo diversa pattuizione delle parti o salvo che, per la natura del contratto o secondo gli usi, risulti congruo un termine minore. Decorso il termine senza che il contratto sia stato adempiuto, questo è risoluto di diritto".

5 Art. 1117 French Code Civil states that "[l] a convention contractée par erreur, violence ou dol, n'est point nulle de plein droit; elle donne seulement lieu à une action en nullité ou en rescission, dans les cas et de la manière expliqués à la section VII du chapitre $v$. du présent titre".
} 
solution for the problems faced by the Italian "rescissione". German law can solve the situations which fall under the Italian "rescissione" using the $\S 138 \mathrm{BGB}^{6}$.

These examples show that translating legal terms from common law system to civil law systems is as dangerous as translating legal terms of systems belonging to the same legal tradition.

\section{The lack of coherency of the European legislator and its impact in the national process of implementation of European Directives}

The difficulties encountered in the conceptualization of contract increase if we take into account the European legislation and, especially, the transposition of European Directives in all official languages of the Member States.

The difficulties are in some part consequence of the political and diplomatic nature of the European legislation (GALLAS, 2006, pp. 171-172). The European legislation is the result of a complex process of negotiation among States, focused more on the interests which have to be protected than on coherency (IORATTI FERRARI, 2005, p. 1560). These concepts are vague and neuter, being difficult to find terms which have equivalent legal meanings in all languages of the Member States. In such situations, the translator may have to resort to a neologism or to the use of the original word. Usually the translator prefers to process the European concepts in the categories of European law system and to adapt the national concepts to the European concepts. This process needs compromises and sacrifices. It could create discrepancies in the national legal categories and concepts. This might decrease the degree of linguistic clearness and precision, introducing a certain degree of ambiguity into the different national systems. In this scenario, a comparative analysis might give better results. Every attempt to make clearer the language of the European legislator must go through a comparative analysis, which takes into account the use and meaning of technical legal concepts inside the national systems. For this reason Professor PALERMO at the conference at Trento University on March 2006 asked the following questions: "Is European law a comparative law, and if it is not in what way should it be? Is comparative law an instrument of legal translation, and if it is not in what degree should it be?" 7

A comparative analysis, focused on legal concepts, might enhance the coherency of the legal terms and concepts by avoiding the absolute casualness which the European legislator has expressed with. The misleading terminology used by the European legislator in drafting the Directives seems one of the main obstacles to the process of harmonisation of contract law. Some

\footnotetext{
${ }^{6}$ Compare § 138 BGB: Sittenwidriges Geschäft; Wucher. (1) Ein Rechtsgeschäft das gegen die guten Sitten verstößt, ist nichtig. (2) Nichtig ist insbesondere ein Rechtsgeschäft, durch das jemand unter Ausbeutung der Zwangslage, der Unerfahrenheit, des Mangels an Urteilsvermögen oder der erheblichen Willensschwäche eines anderen sich oder einem Dritten für eine Leistung Vermögensvorteile versprechen oder gewähren lässt, die in einem auffälligen Missverhältnis zu der Leistung stehen.

7 F. PAlermo, Comparazione giuridica e supporto linguistico. Necessità, Opportunità e Rischi, in La traduzione del Diritto Comunitario ed Europeo: Riflessioni Metodologiche, Conference arranged by Trento University (March $10^{\text {th }}$ and $\left.11^{\text {st }} 2006\right)$.
} 
examples make clear this point. The Italian version of the European Directive 93/13, regarding the unfair contract terms, uses the terms "rescissione" and "recesso" as if they were synonymous, but they are not. The second concept is the power of one the parties to withdraw from a contract 8. Equally, the French version uses the figures of renoncer ${ }^{9}$ and résilier ${ }^{10}$ as if they were synonymous, but again they are not.

The discrepancies among several linguistic versions of the same Directive introduce into European law diverging regulations of the same subject. So the harmonisation of European law, far from being improved, is worsened. Thus linguistic diversity must be seen as one of the main sources of lack of accuracy that must be erased, rather than protected.

The mentioned discrepancies are the result of the translation made by non specialized translators, who do not know the different legal systems, their doctrines and their theoretical models.

Sometimes the misleading terminology used in the Directives has been corrected by the national legislator, but other times even the national legislator has employed a wrong term. A classical example can be the Directive concerning the protection of consumers with respect to contracts negotiated away from business premises, which in its art. 4 introduces the rule of cooling off. In order to express this rule the Italian version of the mentioned European Directive uses the misleading term "rescissione". By reading the Italian version of the Directive, an Italian jurist can be surprised to discover that a consumer can rescindere a contract or an offer (SACCO, 1996, p. 57). According to the Italian Civil Code a contract cannot be rescisso by one of the parties, but only by a judge in the cases provided by the articles 1447 and 1448 of the Italian Civil Code. The party cannot rescindere the contract, the party can only demand the rescissione of a contract. In the same way, an offer cannot be rescissa, it can only be revoked by the party until the contract is concluded, but the terms "revoca"11 and "rescissione" are not synonymous.

\footnotetext{
8 Art. 1373 Italian Civil Code rules the possibility of unilateral withdrawal: "[s]e a una delle parti è attribuita la facoltà di recedere dal contratto, tale facoltà può essere esercitata finché il contratto non abbia avuto un principio di esecuzione. Nei contratti a esecuzione continuata o periodica, tale facoltà può essere esercitata anche successivamente, ma il recesso non ha effetto per le prestazioni già eseguite o in corso di esecuzione Qualora sia stata stipulata la prestazione di un corrispettivo per il recesso, questo ha effetto quando la prestazione è eseguita. E' salvo in ogni caso il patto contrario".

${ }^{9}$ B. Pozzo (2003, p. 764) notices that the term "résilier" refers to the possibility of avoiding a contract, while the term "renoncer" concerns the possibility to resign a claim.

10 B. STARCK, Droit civil, p. 44: "Les contrats successifs ne peuvent pas être résolus car on ne peut pas remettre les choses en l'état antérieur, le locataire qui a eu pendant un certain temps la jouissance d'un appartement, par exemple, ne peut pas rendre au bailleur cette jouissance. Il en résulte qu'en cas d'inexécution des obligations de l'une ou de l'autre partie, un contrat ne pourra être résolu, dans le sens exact de ce terme; il sera éventuellement résilié. La résiliation, à la différence de la résolution, met fin au contrat pour l'avenir, main e peut pas aboutir à une restitution de ce qui a été irrémédiablement fait o acquis". S. BRAUDO, Dictionnaire du Droit Privé (www.tradulex.org): "Que les parties se soient mises d'accord pour mettre fin à leurs relations conventionnelles, ou encore que cette rupture constitue une sanction prononcée par le juge pour inexécution par l'une d'elles de ses obligations, la "résolution" comme la "résiliation" met un terme au lien contractuel. La différence entre la "résolution" et la "résiliation", tient à leurs effets respectifs".

11 Art. 1328 Italian Civil Code rules the "revocation of offer and acceptance" stating that "An offer can be revoked until the contract is concluded. However, if the acceptor has begun performance in good faith before having notice of the revocation, the offeror is bound to indemnify him for the expenses and losses sustained in beginning performance of the
} 
According to the Decreto Legislativo 50/1992, 15 January 1992, which implements the mentioned Directive, the right of rescissione became right of recesso. But even the term recesso is improper. The right of recesso introduced in the process of implementation of the European Directive does not correspond to the concept of recesso provided by the art. 1373 of the Italian Civil Code (AJANI and RossI, 2006, p. 134). As a consequence, a new concept of recesso has been introduced into the Italian system, creating problems of coordination with the old national concept of recesso.

A deeper comparative analysis of the legal concepts, terms and categories belonging to the legal systems of the Member States could enhance coherency at the drafting stage and during the process of implementation of the European Directives. As a result, a comparative analysis could avoid, not only vertical divergences between legal concepts at European and domestic level, but also horizontal divergences among various national legal orders. In this scenario, comparative law can become an important instrument of legal translation.

Let me notice that the legal translation is not an approximate process focused only on the linguistic side, but it is a complex process of interpretation, which focuses on legal terms and concepts. Correct legal terms must be chosen with great care, since the translator works on legal language, his or her interpretation becomes binding law.

Professor AJANI has argued that the translator working on legal language creates law (AJANI and ROSSI, 2006, p. 134). In the analysis of this professor, the boundaries between legal translation and interpretation are unclear and the translation becomes part of a system (AJANI and ROSSI, 2006, pp. 133 - 134). Even if this statement should be verified, it shows the importance that the legal translation has achieved. Especially in an enlarged Europe, legal translation is an important and fundamental part of the process of multilingual drafting of the European Directives and Regulations.

\section{Towards a common legal terminology?}

The principle of linguistic equality was established by the Treaty of Rome in its art. 217 (art. 290 of the consolidated version). Today the mentioned provision and the Council Regulation 1/1958, amended by the Council Regulation 920/2005, is the ground of the principle of linguistic equality. In fact, the art. 4 of the Council Regulation states that "Regulations and other documents of general application shall be drafted in the twenty-one official languages". The principle of linguistic equality is an expression of the principle of equality and the need to guarantee democracy in the process of European integration.

contract. The acceptance can be revoked, provided that the revocation comes to knowledge of the offerer before the acceptance". 
In spite of these provisions, the principle of linguistic equality has been sacrificed in the interest of legal uniformity (URBAN, 2000, p. 55). Thus, with the exception of the European Parliament, the number of European working languages has been reduced in each of the institutions to English, French and German. But the idea that in regard of these three versions of European law a linguistic equivalence of meaning would be possible is unrealistic (URBAN, 2000, p. 54).

Let me notice that between the three languages mentioned the English seems to play a central role in the process of European integration, in spite of a guarantee of linguistic equality provided by the EC through numerous provisions. In addition, most of the international treaties have been drafted in English.

But the English which I refer is legal English from a purely linguistic point of view, but is not a legal English belonging to the common law system. It is a universal and neutral English. It is the English used by the law firms in order to draft documents related to international transactions. It is an English used as a working language in several European legal research networks such as the European Civil Code project and the Acquis Group.

On the one hand, the use of a neutral legal language has more advantages than the use of a traditional legal language, because the last one encounters serious difficulties with regard to the civil law terminology (VAN ERP, 2006, p. 1). In an enlarged Europe the difficulties increase with respect to the translation from common law terms into civil law terms.

On the other hand, the use of neutral legal English has the disadvantage of breaking off the relationship between law and culture (GUILLOREL and KOUBI, 1999, p. 1560). The culture, the history, the social context and the legal system where the legal terms have been developed are important aids, which allow the translator to provide a good translation. Instead, the use of neutral English prevents the translator from searching aids in common law systems and in its culture. Another consequence of the use of neutral legal English is that sometimes the term expressed into neutral legal English has a different meaning, effect and remedies compared to the same term expressed into traditional legal English. For example, in common law the remedy available in case of "breach" is an award of damages. Instead in the United Nations Convention on Contracts for the International Sales of Goods (CIGS) the term "breach" does not necessary imply the remedy of an award of damages (ALPA, 1996, p. 680).

Through this statement I do not want to suggest that, to avoid the problems caused by the principle of linguistic equality, the European Union should choose traditional English or neutral English as a single official language. The choice between the maintenance of linguistic equality or the creation of a uniform legal terminology laid down in a single language or in a limitated number of languages is a political choice, connected with questions of sovereignty and the perception of national self-identity. I would suggest that, even if we continue speaking about linguistic equality and its maintenance, in fact, the English is the language of European economic and cultural relations. Besides, professor VAN ERP has noticed that the "European policy to preserve and cherish linguistic diversity is in clear contradiction with the attempts to create a European Civil Code by working groups that have chosen English as their main language of communication". 
In any case, some authors believe that a common terminology will emerge spontaneously, without any intervention of the EC (IORATTI FERRARI, 2005, p. 1553). For example, professor VAN ERP believes that a nucleus of a common terminology is already happening as a result of European students and teachers exchange programmes. According to VAN ERP, the teachers and students, by studying and teaching in other Member States, exchange information and contribute to a better understanding of legal concepts by students and teachers at both the host and, after their return, the home institution. So they contribute to the creation of a European legal discourse (VAN ERP, 2003, p. 2).

Marie-Jeanne CAMPANA asserts that a common legal language could be the language of case law developed by the European Court of Justice and that it will be developed more easily with a body of jurists educated in the many European institutions (CAMPANA, 2000, p. 45).

LÓPEZ RODRÍGUEZ (2004, p. 1220) believes that a common terminology will emerge as a result of a common legal discourse. According to his view, the European legal profession must be educated towards uniformity and the advantages of seeking inspiration from foreign colleagues.

The European Commission starts to be aware of the need for a common terminology and a common frame of reference. Actually, on February 2003 the European Commission launched an Action Plan where a Common Frame of Reference (CFR) is mentioned ${ }^{12}$. The Common Frame of Reference should provide the best solutions in terms of common terminology and rules, i.e. the definition of fundamental concepts and abstract terms such as "contract", "damage", "indemnity", "rescission" and the rules which apply, for example, in case of non performance (HESSELINK, 2004, p. 403). The CFR can be a database of coherent legal terminology in the field of Contract law. Secondly, it could constitute the basis for a revision of the existing acquis communautaire. The Community could use the CFR in the review and re-formulation of existing EC legislation. Also it could provide guidelines to the European legislator already at the drafting stage of the European Directives and Regulations. Probably the CFR could be the right step towards a more harmonised and coherent European Contract law.

The working language of the CFR project is the English language. Even if the working language of the CFR is only one, it will be translated into other languages. Since, like we asserted before, the translation is often a hazardous and dangerous process rich of hidden traps. Great care should be taken for the translations to be uniform (VAN ERP, 2006, p. 5). As a result, a close collaboration between translators and comparative lawyers is desirable and necessary.

\footnotetext{
12 Commission Communication to the European Parliament and the Council: A More Coherent European Contract Law. An Action Plan.
} 


\section{Some conclusions}

A common European Contract law based on common values is desirable, but it is difficult to achieve because of the lack of a uniform terminology. A common terminology is a prerequisite of every kind of unification or harmonisation of European Contract law. Probably the CFR, which should provide the best solutions in terms of common terminology, concepts and rules, is an important step in the right direction. Since it involves complex problems of translation I would like to claim a central role for the comparative lawyer. Equally, I would like to claim a role for the comparative lawyer as an assistant of the European legislator. This cooperation could improve consistency already at the drafting stage by helping the European legislator to have a deeper understanding of legal terms and concepts. Moreover it could help the European legislator to evaluate the impact of any further legislative act within the Member States.

As regards the process of legal translation of the European Directives, the comparative lawyer might help the translators in choosing legal terms which could be more consistent with the preexistent choice of the European legislator. This could allow a more coherent use of concepts and terms which should not differ from Directive to Directive. In this scenario, comparative law becomes an instrument of legal translation.

But, as argued by IORIATTI FERRARI (2007), "the translation in the field of European Community law, and to a certain extent in the field of European Private law, highlights a dynamic process of continuous linguistic and legal innovation, which is the normal consequence of a supranational legal process". In order to face the problems of translation which are consequence of this dynamic relationship, IORIATTI FERRARI has suggested to use a "methodological bricolage". In other words, the comparative lawyer should use the method that, case by case, he or she deems to be the most appropriate. In fact, there is not a single exclusive method of comparative law, but a sliding scale of methods will always be adapted in terms of specific purposes and practical needs (PALMER, 2005 , p. 290). The comparative lawyer cannot say a priori that one method is better than another, but he or she can choose the most appropriate method on the basis of the practical, new and unexpected problems of legal translation, which he or she have to deal with. In a context where the dynamic relationship between law, language and society is unpredictable, comparative law, with its flexible methods, seems to be the most important tool for legal translation.

For the reasons mentioned above, the collaboration between the European legislator, comparative lawyers and translators should be encouraged. 


\section{Bibliography}

G. AlPA (1996), Corso di Sistemi Giuridici Comparati, Giappichelli, Torino.

G. AJANI and P. ROSSI (2006), "Coerenza del Diritto Privato Europeo e Multilinguismo", in B. Pozzo (ed.), Le Politiche delle Istituzioni Comunitarie dopo l'allargamento, Giuffrè, Milano.

H. Beale, H. KÖtZ, A. HartKamP and D. Tallon (2002), Contract Law, Hart Publishing, Oxford.

E. BETTI (1957), “Causa del negozio giuridico", in Novissimo Digesto Italiano, vol. VII, Torino.

M. BuSSANI and U. MATTEI (2000), Making European Law. Essay on the 'Common Core' Project, Università degli Studi di Trento, Trento.

M. J. CAMPANA (2000), “Versus an langage juridique commun en Europe?”, in Eurpean Review of Private Law.

T. GALLAS (2006), "Il Diritto Comunitario Inteso come Diritto Diplomatico ed il Suo Linguaggio", in B. Pozzo (editor), Le Politiche Linguistiche delle Istituzioni Comunitarie dopo l'Allargamento, Giuffrè, Milano.

G. GANDOLFI (1992), "Pour un code européen des contrats", in Revue Trimestrielle de Droit Civil.

D. J. GERBER (2005), “Authority Heuristics: Language and Trans-system Knowledge”, in B. POzzO (editor), Ordinary Language and Legal Language, Giuffrè, Milano.

H. Guillorel and G. KOUBI (1999), "Introduction", in Langages et Droit, langues du droit, droit des langues, Bruylant, Brussels.

A. HARTKAMP (1994), “The UNIDROIT Principles for International Commercial Contracts and The Principles of European Contract Law", in European Review of Private Law.

M. Hesselink (2004), “The European Commission's Action Plan: Towards a More Coherent European Contract Law?", in European. Review of Private Law.

E. IORIATTI FERRARI (2005), “Lingua e diritto in Europa: Multilinguismo, pluralismo linguistico e terminologia giuridica uniforme nel diritto europeo dei contratti", in Diritto pubblico comparato ed europeo, n. 4.

E. IORIATTI FERRARI (2007), "Introduzione", in E. IORIATTI (editor), La traduzione del diritto comunitario ed europeo: riflessioni metodologiche, Università degli Studi di Trento, Trento.

O. LANDO (2000), "Principles of European Contract Parts I and II", Kluwer Law International. 
A. M. LÓPEZ RODRÍGUEZ (2004), "Towards a European Civil Code without a common European legal culture? The link between law, language and culture", in Brooklyn Journal of International Law.

V. V. PAlmer (2005), "From Lerotholi to Lando. Some Examples of Comparative Law Methodology", in American Journal of Comparative Law.

B. Pozzo (2003), "Harmonising of European Contract Law and the Need of Creating a Common Terminology", in European Review of Private Law.

E. Rotman (1995), "The Inherent Problems of Legal Translation: Theoretical Aspects", in 6 Industrial International \& Comparative Law Review.

R. SACCO (1995), “Contratto in diritto comparato", in Digesto, vol. IV, UTET, Torino.

R. SACCO (1996), "Riflessioni di un giurista sulla Lingua (La Lingua del Diritto uniforme ed il Diritto al Servizio di una Lingua)", in Rivista de Diritto Civile.

R. SACCO (2005), "Language and Law", in B. Pozzo (editor), Ordinary Language and Legal Language, Giuffrè, Milano.

P. W. SCHROTH (1986), "Legal Translation", in 34 American Journal of Comparative Law, Supplement.

H. Schulte-NöLKe, R. SChUlze and L. BernardeAu (eds.) (2000), European Contract law in community, Bundesanzeiger, Köln.

N. Urban (2000), "One Legal Language and the Maintenance of Cultural and Linguistic Diversity?", in European Review of Private Law.

S. VAN ERP (2003), "Linguistic Diversity and a European Legal Discourse”, in Electronic Journal of Comparative Law, vol. 7.3, September.

S. VAN ERP (2006), "European Private Law: A European Standing Committee on Legal Terminology as a Next Step?", in European Journal of Comparative Law, vol. 9.2, July.

W. Van Gerven, J. LeVer and P. Larouche (2000), Tort Law, Hart Publishing, Oxford

C. VON BAR and O. LANDO (2002), “Communication on European Contract Law: Joint Response of the Commission on European Contract Law and the Study Group on a European Civil Code", in European Review of Private Law. 
M. H. Whincup (1996), "Contract Law and Practice. The English system and continental comparison", Kluwer Law International, The Hague. 